\title{
PREMIA AND DISCOUNT OF RICE CHARACTERISTICS: THE CASE OF RETAIL MARKET IN BOGOR-INDONESIA
}

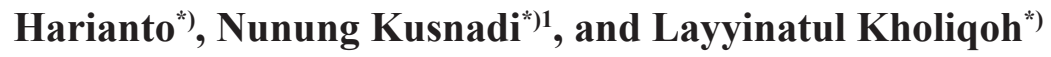 \\ *) Department of Agribusiness, Faculty of Economic and Management, IPB University \\ Jl. Agatis, Campus of IPB Dramaga, Bogor 16680
}

\begin{abstract}
Rice marketing in Indonesia has undergone significant changes, especially at the retailer level. Rice provided by retailers is increasingly diverse, both in terms of variation and quality. This study is aimed at analyzing the implicit value of various characteristics that are generally used as a reference when consumers buy rice at retailers. The study employed a hedonic price model, which was originally introduced by Lancaster. The data used are primary data from the survey of various types of rice sold by retailers in various locations in urban area of Bogor. The survey was conducted in March 2018. The results showed that the content of rice fragments or minute kernels and off-color rice can discount the price of rice. The estimation results of the model also showed that the length characteristic had a negative influence on the price of rice. Rice producers and traders have the opportunity to increase the price of rice they sold by reducing contents of the minute kernel and off-color rice that can be visually observed by consumers when making the choice of rice to buy.
\end{abstract}

Keywords: consumer preference, implicit price, quality attributes, retail market

\begin{abstract}
Abstrak: Pemasaran beras di Indonesia telah mengalami perubahan signifikan, terutama di tingkat pengecer. Beras yang disediakan oleh pengecer semakin beragam, baik dari segi variasi maupun kualitas. Penelitian ini bertujuan untuk menganalisis nilai implisit berbagai karakteristik beras yang umumnya digunakan sebagai referensi ketika konsumen membeli beras di pengecer. Penelitian ini menggunakan model harga hedonis, yang awalnya diperkenalkan oleh Lancaster. Data yang digunakan adalah data primer dari survei berbagai jenis beras yang dijual oleh pengecer di berbagai lokasi di wilayah perkotaan Bogor. Survei dilakukan pada bulan Maret 2018. Hasilnya menunjukkan bahwa kandungan beras patah dan kandungan beras yang berwarna kekuningan ataupun kehitaman dapat mendiskon harga beras. Hasil estimasi model juga menunjukkan bahwa karakteristik panjang beras berpengaruh negatif terhadap harga beras. Produsen dan pedagang beras memiliki kesempatan untuk meningkatkan harga beras yang mereka jual dengan minghilangkan ataupun mengurangi kandungan beras patah dan beras yang berwarna kekuningan yang dapat diamati secara visual oleh konsumen ketika membeli beras.
\end{abstract}

Kata kunci: preferensi konsumen, harga implisit, atribut kualitas, pasar eceran

\footnotetext{
${ }^{1}$ Corresponding author:

Email: nkusnadi@apps.ipb.ac.id
} 


\section{INTRODUCTION}

Rice is still a staple food for the people of Indonesia because it is the main source of carbohydrates and calories. Expenditure on rice for low income groups still occupies a relatively large share of household food expenditure. Thus, the price of rice can have a major effect on the purchasing power of people belonging to this low income class. But in these middle and high income households, their rice consumption tends to shift to rice which is considered to have higher quality. National socioeconomic survey shows that the price of rice paid by high-income households is relatively more expensive than the middle and low income households.

At the retail level the rice market in Indonesia has undergone significant changes. These changes are mainly seen on the retail market in urban areas. Rice consumers no longer only rely on traditional or wet markets as a source of rice purchases. Rice consumers can get rice from supermarkets or rice outlets that are close to their homes instead of at traditional market. Supermarkets and rice outlets outside the traditional market offer a various varieties and quality of rice. The choice of rice varieties faced by consumers is increasing. These various varieties or qualities of rice have different prices per unit of weight.

Rice sold at the retail level cannot be said to be the same or homogeneous. Retailer of rice at traditional markets, supermarkets, or other rice outlets, can carry out product diversification policies or market segmentation. The price of rice included in the packaging can no longer be said to be a price that reflects the balance of market demand and supply. In order to determine rice prices is no longer enough to analyze the factors that influence demand or supply of homogenous product. Analysis of rice prices on a diversified retail market needs to pay attention to the characteristics or quality of rice (Mergenthaler et al. 2009). Research that links directly between the quality of rice and the price of rice in the Indonesian rice market generally uses a qualitative approach in determining the quality of rice studied (Faisal and Lisarini, 2015; Puspitasari et al. 2018). The results of research that used a qualitative approach to the quality of rice certainly have limitations when it comes to formulating policies, at the firm level as well as at market level. The novelty of this research lies in the use of detailed and rigorous measurement methods for each characteristic of rice and directly relates it to price formation.

This study is aimed at identifying and analyzing the influence of rice characteristics on price. The results of the study are not only beneficial for price determination and product strategy formulation for rice producers and sellers, but also are beneficial for the government in formulating more effective rice policies. The characteristics of rice studied are characteristics that appear visually when buyers buy rice at rice outlets. Bio-chemical characteristics such as the content of gluten or the nutrient content in rice are not examined, although these characteristics will determine the quality of rice after being cooked and ready for consumption.

\section{METHODS}

The study was conducted in the Bogor urban area. Site selection was carried out intentionally because based on data of 2017 from Central Bureau of Statistics, Bogor was ranked second as the region with the highest low quality rice samples compared to other regions in West Java. This research sample was taken from a sales point or outlet at the retail level, such as traditional markets, neighborhoods shops, and supermarkets. Data collection is carried out in a range of less than two weeks to avoid changes in the price of rice in the market.

Data obtained through observation and lab testing in March 2018. Observations were made on the location of the sale and recorded the price of rice. The number of rice outlets taken as samples is 45 outlets. The maximum weighs of rice to be purchased are 5 kilograms. At each outlet researchers only buy one package or one type of rice.

The testing procedure for each characteristic component of rice refers to the procedures listed in Indonesia National Standard (SNI) 6128: 2015. Measurements and observations were made on each of the 100 grams of rice taken. Each grain of whole rice is measured in length by using a digital caliper and calculating the average length. The measurement of the weight of each characteristic is carried out using a professional digital scale with a sensitivity of 0.1 milligrams. 
The model used in this research refers to Lucas (1975) model and previous studies related to the implicit price function of goods characteristics. The equation model to be used to analyze the variables affecting the price of rice is as follows:

$$
\begin{aligned}
L n P= & \alpha+\beta_{1} R F S+\beta_{2} C H L+\beta_{3} O C L+\beta_{4} L G T+\beta_{5} L O C \\
& +U
\end{aligned}
$$

Description: $\alpha$ (Intercept (constant)); $\beta 1-\beta 12$ (Coefficient regression of each variable); U (Error term). The description of the variables used in equation model can be looked at Table 1. The above model is analyzed using the ordinary least square (OLS) method. To ensure the model has fulfilled the best linear unbiased estimation requirements, multicollinearity and heteroscedasticity tests are performed.

The important research framework in economic literatures in connecting price of goods to its characteristics is based on the work of Lancaster (1966). The idea presented by Lancaster involves examination of the characteristics or properties of goods as they affect consumers' preferences instead of consideration of the good itself. This suggests that the characteristics of food such as odor, appearance, texture, and nutrient content are the reasons that food is consumed. Rosen (1974) developed Lancaster's thinking by stating that producers can combine various product characteristics to obtain premium prices for the products they produce.

The Lancaster model suffers from a number of limitations. It is possible that some characteristics have negative marginal utilities. The consumption technology relating to characteristics may not be linear. Utility may depend on the distribution of characteristics among products. These issues have been addressed by Hendler (1975), and Lucas (1975). Another limitation of the Lancaster model is that it is formulated in objectively measurable characteristics. Socio-psychological aspects of food, which sometimes have no direct relationship with physical characteristics, are not taken into account. According to Lucas (1975), the general function connecting the characteristics of product to its price was of the form:

$$
P=f\left(C_{i}, G_{j}\right)
$$

Where $\mathrm{P}$ is the price of commodity, $\mathrm{Ci}$ are objective measurable characteristics, and $\mathrm{Gj}$ are state (subjective) characteristics. Outlet or shop environments are examples of state characteristics. The model are widely used in research in the fields of food and agricultural commodities (Espinosa and Goodwin, 1991; Misra and Bondurant, 2000; Chang et al. 2010; Ahmad and Anders, 2012), housing markets (Ellickson, 1981; Wing and Chin, 2003; Pace and Zhu, 2017), and environmental valuation (Gibbs et al. 2002; Deaton and Hoehn, 2004; Martin and Tuttle, 2012).

\section{RESULTS}

\section{Rice Characteristics of Sample}

There are many types of rice with different qualities according to consumer preferences. The quality of rice can be categorized based on the shape and length of rice, the texture, stickiness, and flavor. Nutrient content can also vary between types of rice. In this study, the rice quality factors studied is the characteristics of rice that can be visually observed by consumers when buying rice at the outlet.

If referring to the regulations stated in SNI, the rice selected as the sample does not meet the requirements to be categorized as premium quality rice. Rice fragments content is still relatively high and varies from 0.1 percent to 9.86 with an average of 2.35 percent. In order to be categorized as high quality (premium) rice according to SNI, the content of rice fragments or minute kernel must be 0 percent.

The contents of chalky rice and off-color rice in the research sample also relatively high. There are no samples that are free of chalky rice. The average value of chalky rice content is 5.37 percent, which is far greater than the requirements for being included in the premium rice category which requires 0 percent of chalkiness. Based on the average value of chalky rice content, the rice selected as samples also cannot be categorized as medium quality rice. The medium quality rice category requires not more than 2 percent of chalky rice. Table 2 provides the descriptive statistics of rice characteristics based on sample data. 
Table 1. Description of the variables in equation model of implicit price of rice characteristics

\begin{tabular}{lll}
\hline Symbol & Variable name & Variable explanation \\
\hline RFS & Rice fragments or minute kernel & Rice broken into small pieces not more than 2/10 of whole rice (\%) \\
CHL & Chalkiness & Rice with chalky spot $(\%)$ \\
OCL & Off-color & Rice that is red, green, yellowness, blackish color or damaged (\%) \\
LGT & Length of rice & Millimeter (mm) \\
LOC & Location or type of outlet & Supermarket $=1$, Other $=0$ \\
$\mathrm{P}$ & Price of rice & IDR (Indonesia currency) per Kg \\
\hline
\end{tabular}

Table 2. The Description of rice characteristics based on sample data of rice outlets in Bogor

\begin{tabular}{lcccccc}
\hline \multirow{2}{*}{ Rice Characteristics } & Min. & Max. & Mean & Standard Deviation & \multicolumn{2}{c}{ Rice Quality (according to SNI) } \\
\cline { 5 - 7 } & & & & & Premium & Medium \\
\hline Rice fragments (\%) & 0.10 & 9.86 & $2.35^{* * *}$ & 2.50 & 0 & 2 \\
Chalky (\%) & 1.00 & 16.00 & $5.37^{* *}$ & 2.81 & 0 & 2 \\
Off-color (\%) & 0.00 & 5.00 & $0.80^{* * *}$ & 1.19 & 0 & - \\
Length (mm) & 5.59 & 7.49 & 6.81 & 0.41 & - & - \\
Price (IDR) per kg & 7500 & 17580 & 12245 & 2098 & - & - \\
\hline
\end{tabular}

Description: $* * *$ statistically different from 0 with significant level of $1 \% ; * *$ statistically different from 2 with significant level of $1 \%$

The quality of rice can also be seen from the color. The number of samples free of off-color rice content was only 42 percent. Off-color rice is rice that has red, green, yellowness, blackish colors or damage. The higher the contents of off-color rice, the lower the quality. Premium quality rice requires no off-color rice. The average value of off-color rice in the sample is 0.80 and there are even samples that have off color rice of 5 percent.

The average rice selected as a sample can be categorized as long grain. The average length of rice sample is 6.81 $\mathrm{mm}$. Rice is categorized as a type of long grain if the average rice length is more than $6 \mathrm{~mm}$. While the type of short grain is rice whose average length is not more than $5.2 \mathrm{~mm}$.

\section{Implicit Price of Rice Characteristics}

To ensure that the model used in this study has met the requirements of econometrics as a good and fit model, multicollinearity and heteroskedasticity tests were carried out. Multicollinearity test is done by looking at the variance inflation factor (VIF) value of each variable used in the model. Based on model estimation the highest VIF value is 2.3 which is owned by the rice fragments variable, and the lowest is the off-color variable with a VIF value of 1.2. Thus it can be stated that the model is free from multicollinearity problems.
For the heteroscedasticity test, the Glejser method is used. Heteroscedasticity is a problem often associated with cross sectional data. The Glejser test results in this study indicate that the coefficient of all independent variables employed in the model have significant level value much higher than 0.005 . So, it can be concluded that there is no heteroscedasticity problem in the model used. Further, $\chi^{2}$ significant value of observed R2 is 0.526 and much greater than 0.05 level of significance. This indicates that the research model employed is free from heteroscedasticity problems.

The Durbin-Watson $d=2.032$, which is between the two critical values of $1.5<\mathrm{d}<2.5$. Therefore, there is no first order linear auto-correlation in multiple linear regression data.

Table 3 presents the estimation results of the model implicit price of rice characteristics used in this study. The model can explain very well the variation of rice prices. This is indicated by the high value of $\mathrm{R} 2$ of 74.8 percent . Independent variables in the model have an influence on the dependent variable in the direction that is in accordance with the expectations. Of the 5 independent variables there are 3 variables that significantly affect the price of rice at the retail level. These variables are rice fragments, off-color rice, and length of rice. While the chalkiness and location variables are not statistically significant. 
Table 3. The results of estimation implicit price of rice characteristics model

\begin{tabular}{lccccc}
\hline \multicolumn{1}{c}{ Characteristics } & Coefficient & Standard error & $\mathrm{t}$ & Sig. & Implicit price of characteristics (IDR per Kg) \\
\hline (Constant) & 10.170 & 0.265 & 38.354 & 0.000 & - \\
Rice fragments & $-0.042^{* * *}$ & 0.009 & -4.755 & 0.000 & -459.60 \\
Chalky & -0.004 & 0.006 & -.736 & 0.466 & -60.22 \\
Off-color & $-0.035^{* *}$ & 0.017 & -2.047 & 0.047 & -346.55 \\
Length & $-0.093^{* *}$ & 0.041 & -2.297 & 0.027 & -1357.41 \\
Location & 0.019 & 0.036 & 0.517 & 0.608 & 279.43 \\
\hline
\end{tabular}

R Square $=0.748 ;$ Adj. $\mathrm{R}$ Square $=0.715 ; \mathrm{F}$ stat $=23.126^{* * *} ; \mathrm{DW}=2.032$

Description: $* * *$ significant at $1 \%$ level; $* *$ significant at $5 \%$ level

Rice fragments variables have a statistically significant effect on the price of rice with a significance level of 1 percent. Rice fragments or minute kernel, in Indonesian called menir, are rice broken into small pieces. Rice fragments are broken rice whose size is not more than $2 / 10$ whole rice, and is not categorized as rice because the size is too small (Wariyah, 2010). The higher the content of rice fragments, the rice is categorized as the lower quality. Regression analysis results show the negative effect of rice fragments on price of rice. The greater the content of rice fragments will reduce the price of rice. Regression results show every one percent increase in the content of rice fragments will cause a price decrease by 4.2 percent. Based on the coefficient in the model implicit value of rice fragments can be discounted, which is obtained by the value of minus 459.60 IDR of every one percent increase in rice fragments.

Off-color content also negatively affects the price of rice. The greater the percentage of off-color content, the lower the price of rice. Every one percent decrease in off-color content will increase rice prices by 3.5 percent. The implicit value of the off color content can also be calculated from the magnitude of the coefficient in the model. Every one percent decrease in off-color content, the price of rice will increase by 60.22 IDR. Color changes in rice mainly occur during the storage, which is also called the aging process (Thanatornvarakul et al. 2016). Factors affecting the aging process during storage are storage time, temperature, and moisture content (Zhou et al., 2015). The more off color rice content, meaning that the rice has been stored for a long time or the conditions of temperature and moisture content unsuitable during storage.

Rice (Oriza sativa) in Asia is categorized into two major categories, namely long grain or indica rice and short grain or japonica rice. Short grain rice variety tends to stick together when cooked. Rice sushi or Japanese rice is short grain variety. In contrast, long grain rice tends to remain separate when cooked. Basmati rice or Indian rice is classified as long grain. Indonesian rice consumers prefer pulen rice or rice that sticks together when cooked rather than rice that is pera or is remain separated when cooked. Short grain rice is valued more expensive by consumers than long grain rice. Based on regression results, the length variable had negative effects on the price of rice. The implicit price for each millimeter $(\mathrm{mm})$ of reduced length of rice is 1357.41 IDR.

Although statistically insignificant, the results of this study also indicate that chalky rice carries a discount on the price of rice. The higher the content of chalky rice is the lower the quality of rice. Based on SNI the content of chalky rice should not be more than 2 percent for rice can be categorized as medium rice. Premium rice requires zero percent of chalky rice. Chalkiness in rice is marked by the color of the opaque instead of translucent. Yoshioka et al. (2007) found improper weather conditions at the time of maturation of rice grains lead to an incomplete enzymatic process, thus affecting the quality of rice produced. One quality of rice affected is in the form of chalky rice.

Based on Indonesia's trade minister's regulation number 57 of 2017 concerning the highest retail price of rice, the price of medium quality rice and premium quality at the retail level should not be higher than 94500 IDR and 12800 IDR respectively. The price spread between medium quality rice and premium quality rice based on the trade minister's decision is 3350 IDR.

The location of outlets where rice is marketed is initially expected to affect rice prices. In this study location dummy variable is rated 1 if rice was sold in supermarkets and 0 if others. Location variables are 
expected to capture the shopping environment which is certainly expected to affect the price of products sold. Although there are indications that rice sold in supermarkets tends to be more expensive than rice sold elsewhere, this study found that location variables did not have a significant effect on price differences. Rice consumers attach the same price for rice with the same characteristics regardless of location.

\section{Managerial Implications}

The results of this study have managerial implications for consumers and rice retailers. For consumers, determining the quality of rice is not enough to rely on claims written in the packaging, but also requires a detailed visual inspection of the physical rice to be purchased. For retailers, rice sold on the market still has the opportunity to improve its characteristics and can get a higher price. Rice retailers can ask rice producers to supply rice according to SNI standards. If rice supplied is included in the category of premium rice, then there should not be chalkiness, minute kernel, or off-color rice.

\section{CONCLUSIONS AND RECOMMENDATIONS}

\section{Conclusions}

Contrary to claims in the packaging of several samples which claim to be premium rice, none of the research samples can be categorized as premium rice. The premium rice category requires that there should be no off-color, minute kernel, or chalkiness rice. There is no sample that is free from chalkiness and minute kernel or rice fragments. The content of rice fragments or minute kernels and off-color rice are statistically significant to reduce the price of rice. The implicit value of each percent of rice fragments is 459 IDR or 4.2 percent of the price, and implicit price discounting for off-color is 346 IDR or 3.5 percent. Short grains of rice command a higher price than long grain. However, the characteristics of rice depend on rice varieties and are outside the policies that can be carried out by retailers.

\section{Recommendations}

The government can improve the rice marketing system by requiring all rice retailers to package rice they sold with transparent materials that allow consumers to assess the characteristics of the rice they want to buy.
The government also needs to strictly supervise the quality label listed in packaging of rice to conform to SNI rules.

\section{REFERENCES}

Ahmad W, Anders S. 2012. The value of brand and convenience attributes in highly processed food products. Canadian Journal of Agricultural Economics 60(1):113-133. https://doi. org/10.1111/j.1744-7976.2011.01234.x.

Chang JB, Lusk JL, Norwood FB. 2010. The price of happy hens: A hedonic analysis of retail egg prices. Journal of Agricultural and Resource Economics 35(3):406-423.

Deaton BJ, Hoehn JP. 2004. Hedonic analysis of hazardous waste sites in the presence of other urban disamenities. Environmental Science and Policy 7(6):499-508. https://doi.org/10.1016/j. envsci.2004.08.003.

Ellickson B. 1981. An alternative test of the hedonic theory of housing markets. Journal of Urban Economics 9(1):56-79. https://doi. org/10.1016/0094-1190(81)90048-6.

Espinosa JA, Goodwin BK. 1991. Hedonic price estimation for Kansas wheat characteristics. Western Journal of Agricultural Economics 16(1):72-85.

Faisal, M.R., and Lisarini, E. 2015. Pengaruh kualitas dan harga beras pandanwangi terhadap kepuasan konsumen di wilayah pemasaran Cianjur. Jurnal Agroscience 5(2): 1-6.

Gibbs JP, Halstead JM, Boyle KJ, Huang J. 2002. An hedonic analysis of the effects of lake water clarity on New Hampshire lakefront properties. Agricultural and Resource Economics Review 31(1):39-46. https://doi.org/10.1017/ S1068280500003464.

Hendler R. 1975. Lancaster's new approach to consumer demand and its limitations. American Economic Review 65: 194-200.

Lancaster KJ. 1966. A new approach to consumer theory. Journal of Political Economy 74:132157. https://doi.org/10.1086/259131.

Lucas REB. 1975. Hedonic price function. Economic Inquiry 13: 157-178. https://doi.org/10.1111/ j.1465-7295.1975.tb00985.x.

Martin DH, Carrie M, Tuttle CM. 2012. Values in the wind: a hedonic analysis of wind power facilities. Land Economics 88(3):571-588. https://doi. 
org/10.3368/le.88.3.571.

Mergenthaler M, Weinberger K, Qaim M. 2009. Consumer valuation of food quality and food safety attributes in Vietnam. Review of Agricultural Economics 31(2): 266-283. https:// doi.org/10.1111/j.1467-9353.2009.01437.x.

Misra SK, Bondurant J. 2000. The role of product and market characteristics in determining cottonseed prices. Agribusiness 16(3): 357-366.

Pace P, Zhu S. 2017. Implicit hedonic pricing using mortgage payment information. Journal of Real Estate Finance and Economics 54(3): 387-402. https://doi.org/10.1007/s11146-016-9578-8.

Puspitasari I, Sumampouw HJ, Punuindong AY. 2018. Pengaruh kualitas produk dan kesesuaian harga terhadap peningkatan penjualan beras premium pada Perum Bulog divisi regional Sulawesi Utara dan Gorontalo: Studi kasus padakKonsumen wilayah Kota Manado. Jurnal Administrasi Bisnis 6(2):59-67.

Rosen, S. 1974. Hedonic prices and implicit markets: Product differentiation in pure competition. Journal of Political Economy 82(1): 34-55. https://doi.org/10.1086/260169.

Thanatornvarakul N, Anuntagool J, Tananuwong K. 2016. Aging of low and high amylase rice at elevated temperature: Mechanism and predictive modeling. Journal of Cereal Science 70:155163. https://doi.org/10.1016/j.jcs.2016.06.004.

Wariyah, C. 2010. Restructured fine grain rice to high calcium rice by extrusion method. Agritech 30 (3):135-140.

Wing CK, Chin TL. 2003. A critical review of literature on the hedonic price model. International Journal for Housing Science and Its Applications 145-165.

Yoshioka Y, Iwata H, Tabata M, Ninomiya S, Ohsawa R. 2007. Chalkiness in rice: Potential for evaluation withimage analysis. Crop Science 47:2113-2120. https://doi.org/10.2135/cropsci2006.10.0631sc.

Zhou Z, Wang X, Si X, Blanchard C, Strappe P. 2015. Ageing mechanism of stored rice: A concept model from the past to the present. Journal of Stored Products Research 64:80-87. https://doi. org/10.1016/j.jspr.2015.09.004. 